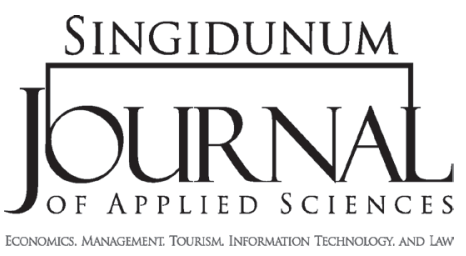

SINGIDUNUM JOURNAL 2013, 10 (1): 18-27

ISSN 2217-8090

UDK: 330.341.4(497.6)"2006/2010" ;

005.332:338.124.2(100); 330.101.54

DOI: $10.5937 / \mathrm{sjas} 1301018 \mathrm{M}$

Review paper/Pregledni naučni rad

\title{
DIRECTIONS AND GUIDELINES FOR RESOLVING THE CRISIS (IN BOSNIA AND HERZEGOVINA AND ITS ENTITIES)
}

\section{Zoran Mastilo*}

University of East Sarajevo, Faculty of Business and Economics

133 Račanska Street, Bijeljina, Republic of Srpska, Bosnia and Herzegovina

\begin{abstract}
:
This is a global financial and economic crisis, which can be considered the largest since the World War II. It has become a frequently discussed topic by various analysts, numerous governments, and in particular, a favourite topic of the media. We can rightly say that this is a crisis of the neoliberal system, which has greatly increased the wealth of the rich and impoverished the poor. Such crisis can be overcome by changing the system. Therefore, the directions and guidelines are necessary in order to determine the goals for resolving the crisis. The defined key objectives must be accompanied by specific sub-objectives, followed by establishing certain policies, which will contribute to the realization of these goals. We need to advocate and implement policies that will assist in accomplishing the defined goals. Some of those policies include the following: industrial policy, fiscal policy, monetary policy, regional development policy, public administration policy, and social policy.
\end{abstract}

\author{
Key words: \\ global crisis, \\ macroeconomic indicators, \\ neo-liberalism, \\ general well-being of a country, \\ fiscal policy, \\ industrial policy, \\ resolution, \\ directions and guidelines.
}

\section{INTRODUCTION}

The crisis has influenced the whole world. Therefore, it has the dimension of a large global financial and economic crisis, and it can be considered the greatest crisis since the Second World War. The fear of further development of the crisis affects everyone, especially the employees as it contributes to higher unemployment rates. The global crisis has been discussed and written about more than any other natural or social disaster that could affect the world, such as global warming, solar flare that could hit the Earth at the end of 2012 and revert our way of living back to the XIX century. Likewise, frequent alleged outbreaks of epidemics: mad cow disease, bird flu and swine $\mathrm{flu}^{1}$, terrorism and similar occurrences,

1 It is said that the financial crisis and the swine flu virus H1N1 were deliberately caused. Pharmaceutical lobby is associated with the induction of all these outbreaks. It wo- as well as numerous neuralgic points in the world today - Iraq, Afghanistan, Iran, Middle East, North Korea, the Balkans and others. It represents both an opportunity and a challenge, when the economic theories and policies are put to the test. The question that could be rightly asked is "What is required from the economic system?" If the goal is only to make profit and not the well-being of the society, then such direction leads to the crisis and unsustainable economic growth. It is necessary to govern and adjust the market in order to successfully manage the economy. The characteristics of the existing systems are the lack of regulation of market defi-

uld be interesting to analyze the possible intent of provoking a financial crisis. It would lead to some key managers of financial institutions. For instance, one of the two largest U.S. mortgage companies, Freddie Mac, was warned about the crisis in 2004. However, the general manager of that company resigned, alongside with a large financial bonus before the crisis outbreak. 
ciencies, externalities and social inequalities. Still, there is no complete and clear answer on how to deal with, and how to combat the crisis. It started after a long period of rapid credit growth, low risk premiums, high liquidity, asset price growth and "pumping" of the actual estate prices. During 2007 and the first half of 2008, a shocking increase in food and energy prices occurred, which further accelerated the global crisis. It resulted in a rapid deterioration of the economic situation. Over 100 million people in developing countries have been pushed into poverty. Due to different levels of development and different economic structure, consumption and globalisation, such substantial increase in food and oil prices had a greater impact on poverty increase than the economic crisis during the 2008-2009 period, which (by 2010) pushed 64 million people into poverty (World Bank, 2010). Since 1970 until 2008, the world has been through 124 banking crises, 208 currency exchange crises, 63 debt crises, 42 double and 10 triple crises (Pollin, 2009). Charles Kindleberger states that since 1725 up to date, financial crises have been occurring in the Western capitalist economies every eight and a half years, on average (Jurčić, 2011). We can rightly say that this is a crisis of a neoliberal system, and the resolution of the crisis should be sought in the alternative economic - political systems.

\section{How well are we informed about the political-economic crisis?}

Previous information about the crisis has not been sufficient to reach a resolution. This has been an attempt to analyse the crisis and overview the environment in which it occurs.

We wonder whether the current neo-liberal political and economic system is appropriate or not. Namely, as the basic cause of the crisis, it must have some disadvantages.

Opinions are divided when it comes to the causes of the crisis. The fact that is even worse is that there are various proposals regarding directions and guidelines for resolving the crisis. It is certain that the mortgage loans have triggered the crisis on financial markets of the United States. This does not exclusively refer to the loans in general, but to the loans colloquially called "sub-prime" loans (Puljić, 2009). We translate such loans as the second class loans, while, in fact, they represent the high risk loans, as they are granted to customers with no loan repayment capability and adequate coverage (Puljić, 2009).
With the fall of socialism in the early 90 -ies of the last century, history seems to be definitely sided with liberal capitalism, marking it as the undisputed winner and the universal model for the future organisation of the world.

\section{THE NEGATIVE EFFECTS OF THE GLOBAL CRISIS IN BOSNIA AND HERZEGOVINA AND ITS ENTITIES COMPARED TO THE INTERNATIONAL ENVIRONMENT}

\section{Macroeconomic indicators of the environment}

What remains a problem is that the unemployment rates have increased, and adversely affected the GDP of each country; the fiscal position has worsened, while the public debt has increased. Croatia, Montenegro and Romania have recorded a decline in GDP in the past year, while in other countries, the growth of real GDP was ranging from $0.4 \%$ in Bulgaria to 3\% in Albania. The global crisis has not yet finished, but compared to 2009, the situation is slightly better. The inflation in most countries of Southeast Europe increased significantly, so that at the end of 2010, the inflation rate in Bosnia and Herzegovina was $2 \%$, while the highest inflation was recorded in Romania amounting up to $7.9 \%$.

The most positive growth trend in the European Union was recorded in Germany, mostly due to the increased export and financial stabilization. During 2010 , the real GDP rose by $1.7 \%$ in the euro zone and by $1.8 \%$ in EU27. The recession in 2009 led to the drop in real GDP by $4.1 \%$ in the euro area and by $4.2 \%$ in the EU27. The annual inflation in the euro zone was $2.2 \%$ and $2.6 \%$ in the EU27. The whole world is eagerly waiting for the global economic recovery. The most expectations were present in 2010, but the recovery took place at a different pace. According to estimates from the International Monetary Fund, the global economic growth was at $4.6 \%$. The recovery of the economy in 2010 was more noticeable in the U.S. than in Europe and Japan. With respect to the U.S. and their economy, the second half of 2010 can be considered the period in which the recovery took place at a slower pace than in the first half of the year. The largest problem that remains is the high unemployment rate, amounting to $9.1 \%$ in 2010 with the average inflation rate of $1.7 \%$. 


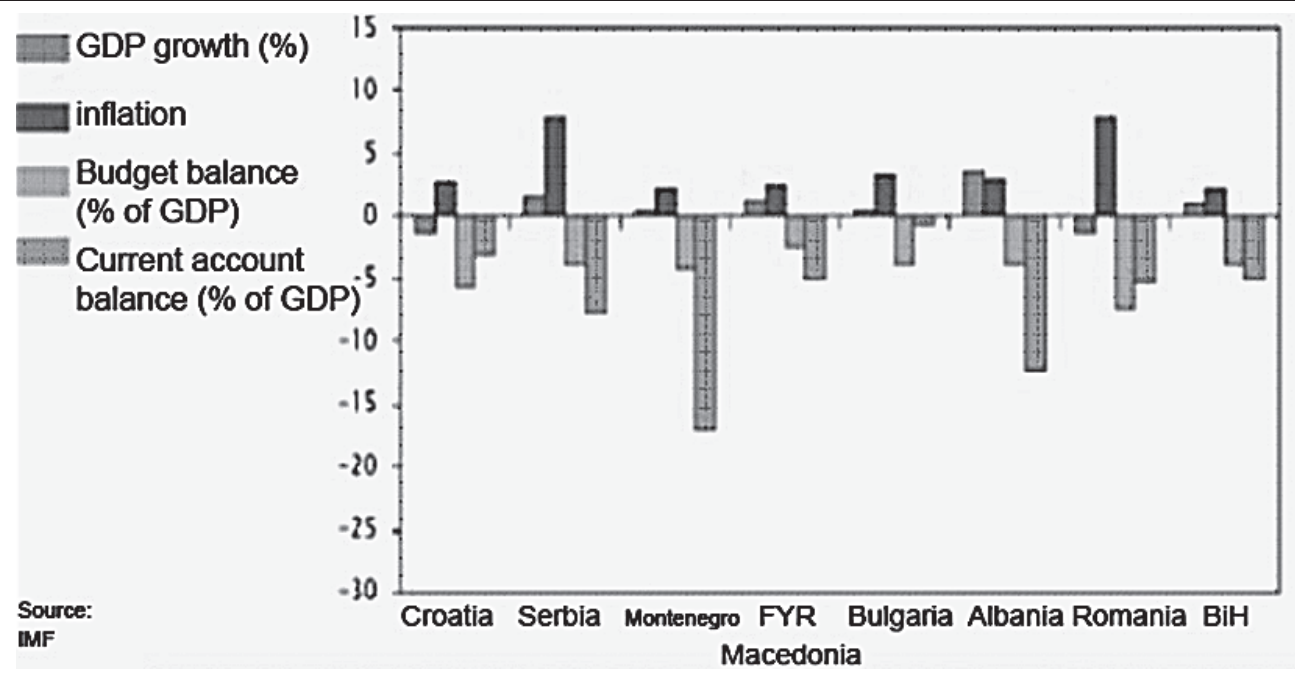

Chart No. 1: Main economic indicators for the countries of Southeast Europe in 2010.

Source: www.imf.org

Table 1: Real GDP growth rate

\begin{tabular}{lcccc}
\hline & 2009 & 2010 & 2011 & 2012 \\
\hline World & -0.5 & 5.0 & 4.4 & 4.5 \\
\hline USA & -2.6 & 2.8 & 2.8 & 2.9 \\
\hline Euro zone & -4.1 & 1.7 & 1.6 & 1.8 \\
\hline Japan & -6.3 & 3.9 & 1.4 & 2.1 \\
\hline Central and Eastern Europe & -3.6 & 4.2 & 3.7 & 4.0 \\
\hline Bosnia and Herzegovina & -3.1 & 0.8 & 2.2 & 4.0 \\
\hline
\end{tabular}

Source: www.imf.org

\section{Macroeconomic indicators in Bosnia and Herzegovina (B\&H) and its entities}

Bosnia and Herzegovina and its entities are faced with the strong negative effects of the global crisis. Such adverse effects of the crisis are manifested in a decline of GDP, rise of unemployment, reduced industrial production, reduced foreign direct investments and public budget deficit.

Bosnia and Herzegovina and its entities need a rapid economic recovery and development, the macroeconomic stability. The crisis and the recession have shaken the whole world (the EU countries, countries in the region). Thus, $\mathrm{B} \& \mathrm{H}$ and its entities are faced with strong negative effects of the global crisis. Even before the recession, the prominent structural disorders and "slower progress of structural reforms" (the euphemistic term that the World Bank uses to describe unsuccessful structural reforms) would make the cyclical recovery of $\mathrm{B} \& \mathrm{H}$ much more difficult, and much painful and longer than in other countries, due to external and internal failures (Hodžić, 2010).
The Governments and government measures in the entire $\mathrm{B} \& \mathrm{H}$ could have and must have done much more. We can freely say that the Government productive measures were missing, which could mitigate the negative effects of the global economic crisis. We cannot say that the governments have not done anything, but the effects of their acts have been inefficient in all segments of the society.

This graph shows the progress of nominal GDP and the growth rate of real GDP in B\&H for the period 2006-2010. It is clear from the graph that the global crisis has negatively affected GDP of Bosnia and Herzegovina.

The largest negative effects and the disturbances were visible in the labour market, which has remained undeveloped, and which has suffered severe "shocks", but was not completely devastated.

Rising unemployment is changing from month to month with the largest number of the unemployed (522.052 people) recorded in December 2010.

When it comes to the employment, the number of employees in 2010 had a decreasing trend. According to the Agency for Statistics in $\mathrm{B} \& \mathrm{H}$, the 
average number of employees in Bosnia and Herzegovina in 2010 was 681.656 people.

As far as the fiscal sector is concerned, we can say that it is an unstable zone, as public budgets have become unsustainable and are faced with very large deficits. The current governments do not contemplate on the public spending and its reduction and do not work on bringing it in line with the international standards. The reduction of public spending in such conditions can be considered as an essential precondition for macroeconomic stability in $\mathrm{B} \& \mathrm{H}$ and its entities. The public budgets had become unsustainable even before the crisis hit, especially taking into consideration a set of ambitious welfare legislations and appropriations for these categories, which was used for obtaining the political support for the current government at the expense of taxpayers. This has led to a financial imbalance and triggered the instability in $\mathrm{B} \& \mathrm{H}$, as well as numerous job losses.
Mastilo Z. $\diamond$ Directions and guidelines for resolving the crisis

The global crisis in B\&H and its entities affected the industrial production as well, its effects were negative. Thus, in 2009 the industrial production decreased by $3.3 \%$ compared to 2008 , while in 2010 , a slight increase in industrial production of $1.6 \%$ was recorded compared to 2009. Industrial production, as an important macroeconomic aggregate of GDP in B\&H, occupies the central position, since it accounts for about $21 \%$ of the total GDP. The situation was not ideal at the beginning. Namely, in the circumstances of the global economic crisis, the industry showed signs of serious, hopeless deterioration. However, it still managed to improve and record a positive trend.

Entities in $\mathrm{B} \& \mathrm{H}$ (FB\&H and RS) in the last few years have achieved an average growth rate of industrial production of $2.9 \%$ in FB\&H and $12 \%$ in the Republic of Srpska.

When it comes to foreign direct investment (FDI), Bosnia and Herzegovina does not excel in

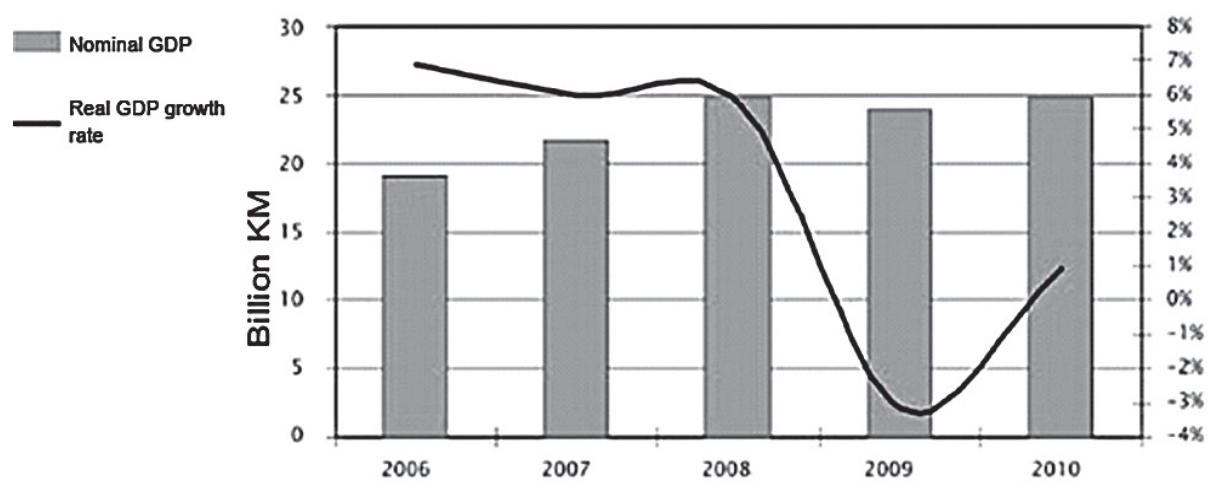

Chart No 2: Nominal GDP and the growth rates of real GDP

Source: www.cbbh.ba

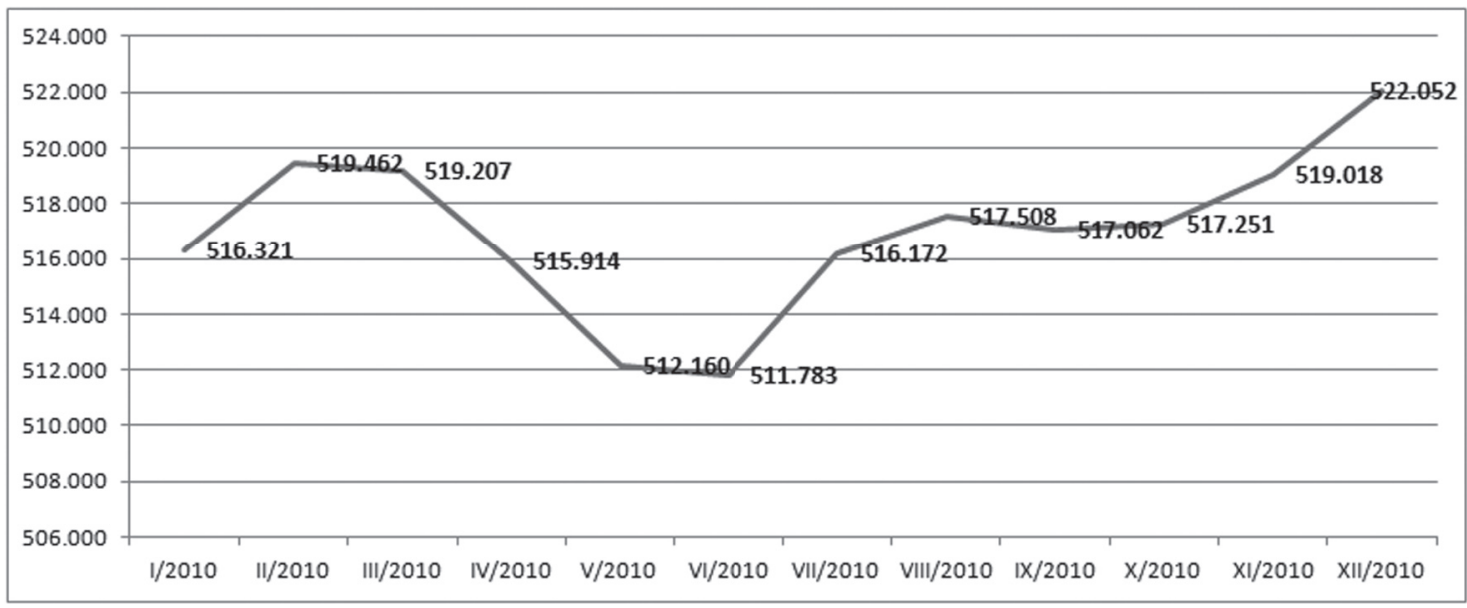

Chart No. 3: Progress of registered unemployment in B\&H in 2010

Source: www.arz.gov.ba 


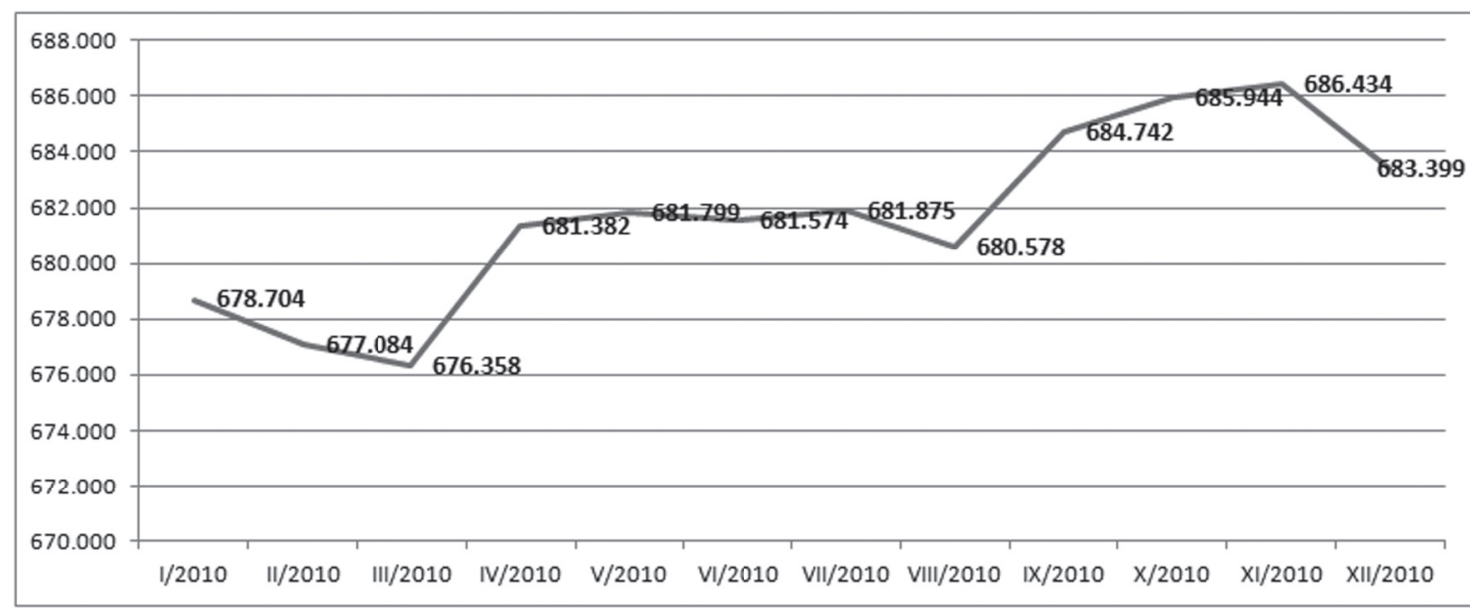

Chart No. 4: Progress of registered employment in B\&H in 2010

Source: www.arz.gov.ba

\begin{tabular}{lccc}
\hline & B\&H & FB\&H & RS \\
\hline C-Mining & 96.2 & 95.7 & 109.1 \\
\hline D-Manufacturing & 101.9 & 106.9 & 105.1 \\
\hline E-Electricity, gas and water & 103.7 & 102.4 & 103.0 \\
\hline TOTAL INDUSTRY & 101.6 & 104.2 & 105.0 \\
\hline
\end{tabular}

Table no. 2: Industrial Production Indices $(2009=100)^{3}$

Source: www.cbbh.ba

this macroeconomic indicator. The global crisis has produced profound negative effects and foreign investors tend to avoid investing in Bosnian market. Generally speaking, the negative effects of macroeconomic aggregates have influenced adversely other macroeconomic aggregates, mostly the GDP and the labour market.

By comparing the investments in the fourth quarter of 2011 in the amount of 130 million KM and the
FDI in the fourth quarter of 2010, it is clear that the former was about 2.7 times higher compared to the actual values in the fourth quarter of 2009 when the recorded values decreased by $29.5 \%$. The total foreign investment in 2011 (392 million KM) decreased by 17.2\% compared to data in 2009 (473 million KM).

The above analysis clearly shows that the level of total foreign investments in $\mathrm{B} \& \mathrm{H}$ in recent years has been in decline, which is badly assessed. Research

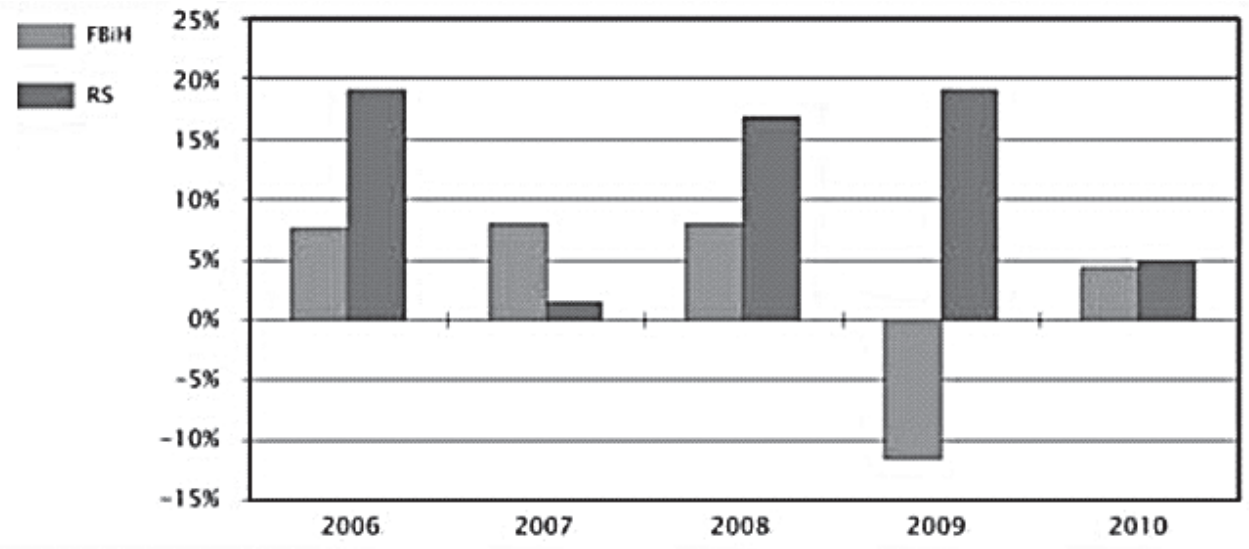

Chart No. 5: Annual growth rates of industrial production, 2006-2010.

Source: www.cbbh.ba 
shows that the investments in Albania were higher in relation to Bosnia and Herzegovina (Albania-827 million). The main barrier to the arrival of foreign investors in $\mathrm{B} \& \mathrm{H}$ should be the political reason, since the country has not got the political stability, which is essential for economic development.

When it comes to competitiveness, B\&H cannot boast about that indicator, as it belongs to the least competitive economies. The Economy of Montenegro, Romania, Latvia, Greece, Croatia, Bulgaria, Ukraine, Macedonia, Serbia, and Albania is more competitive than that of Bosnia and Herzegovina, thus leaving Bosnia and Herzegovina in the last place. This is not surprising as $\mathrm{B} \& \mathrm{H}$ does not have sufficient political stability. It took a year after the elections held in October 2010 to form the Council of Ministers (in February 2012) that needs to initiate economic reforms in terms of economic recovery that is essential for $\mathrm{B} \& \mathrm{H}$. Now it is up to $\mathrm{B} \& \mathrm{H}$ and its Council of Ministers and their actions to make the economy of $\mathrm{B} \& \mathrm{H}$ more competitive.

It is very interesting to observe the GDP of Bosnia and Herzegovina per capita. When expressed in purchasing power standards, it was only $30 \%$ of the average EU $27=100$ in 2010. The situation in 2010 was worse than in 2009 , when it was $31 \%$. The fig- ures for Albania were 27\% in 2009 and 29\% in 2010, which shows a better, increasing trend with respect to Bosnia. The situation is much better in other countries of former Yugoslavia (Slovenia amounting up to $88 \%$ in 2009 and $87 \%$ in 2010, while in Macedonia it was $36 \%$ in 2009). The most prominent example is Luxembourg, whose GDP per capita was $283 \%$ above the EU average in 2010, which is the highest level of development.

These analyses indicate that the crisis and its negative effects are deeply rooted in a small economy such as the economy of B\&H. Therefore, we believe that it represents a great test of politics and economy on the global level, and likewise in Bosnia and Herzegovina and its entities.

\section{Macroeconomic indicators of the Republic of Srpska}

These indicators show the macroeconomic situation in the Republic of Srpska (RS). The macroeconomic indicators of the Republic of Srpska are presented here, for the period 2007-2011, which is the period when the crisis produced adverse effects on $\mathrm{B} \& \mathrm{H}$ and its entities. The macroeconomic indicators of the Republic of Srpska say much, and it is

Investment (FDI) per quarter in 2009, 2010 and 2011 amount to:

\begin{tabular}{lccccc}
\hline Millions of KM & K1 & K2 & K3 & K4 & Ukupno \\
\hline 2009 & -6.4 & 160.8 & 134.2 & 184.4 & 473.00 \\
\hline 2010 & 57.9 & 23.3 & 6.2 & 48 & 135.00 \\
\hline 2011 & 93 & 61 & 108 & 130 & 392.00 \\
\hline
\end{tabular}

Table no. 3: Investments by quarter (in millions) in 2009, 2010 and 2011.

Source: www.dep.gov.ba

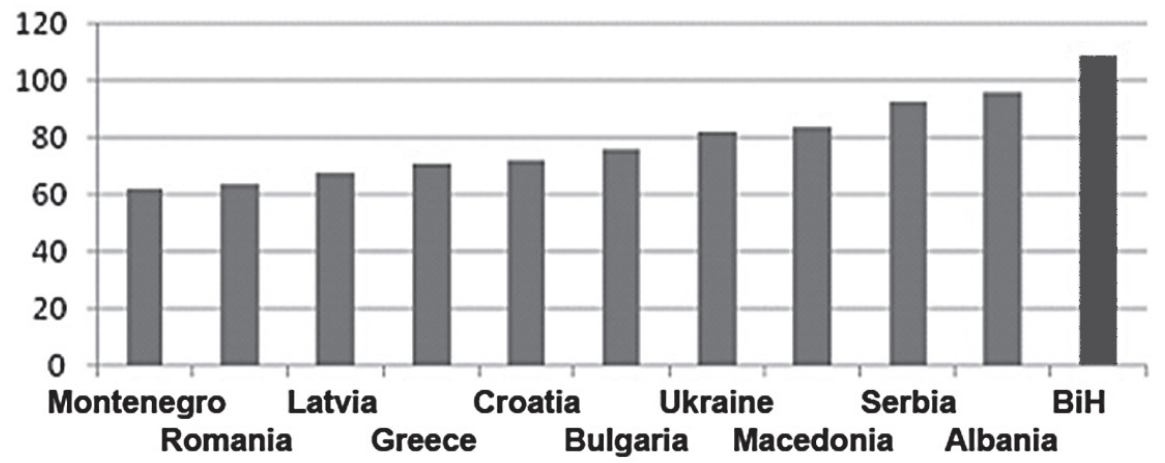

Chart No.6: WEF 2009-10:11 The least competitive European economies

Source: www.weforum.org 


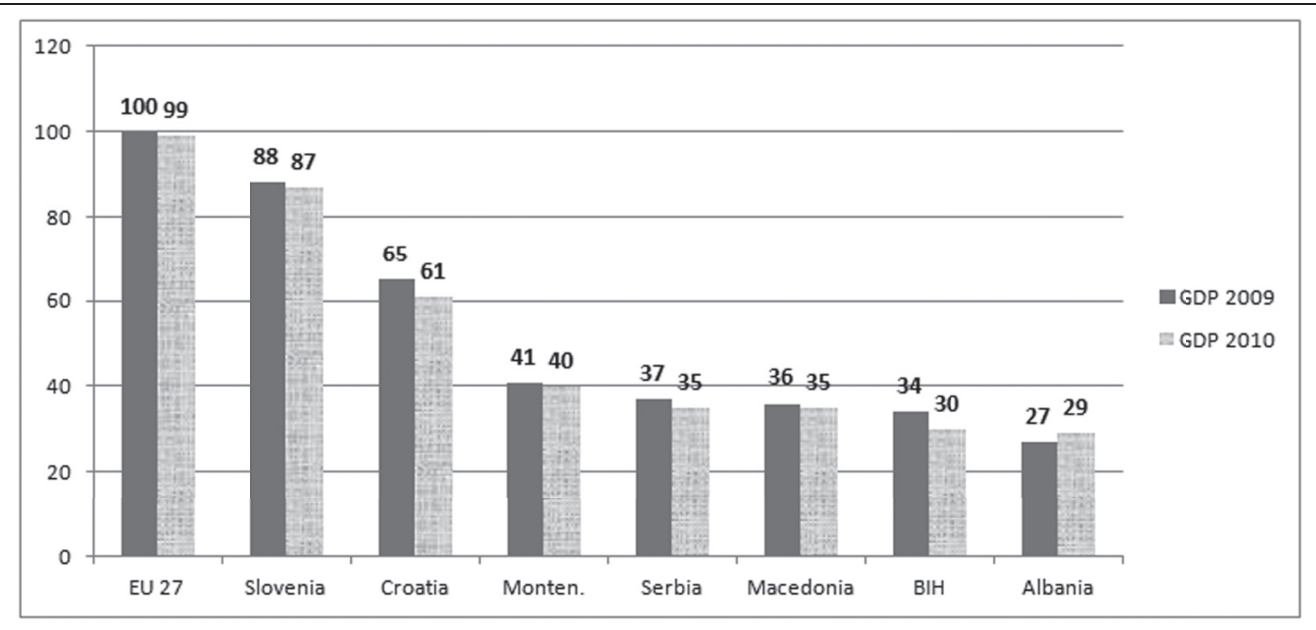

Chart No.7: Gross domestic product per capita.-Purchasing power standard; -EU27-100

Source: www.bhas.ba

necessary to do some further work, by searching for directions and guidelines for resolving the crisis. As obvious from this review, the largest problem in the Republic of Srpska is the high unemployment rate, which increased for 13.710 people during the period (2007-2011), which is a lot for such a small economy as the economy of the Republic of Srpska.

If we look at a nominal value of the GDP in 2010, we can see that it was 8.31 billion KM, while the GDP per capita (GDP per capita) was $5797 \mathrm{KM}$, which is something we cannot boast about.

The rates of real GDP growth (\%) for the period (2006-2010) have variable trends. Fluctuations of the rate of real GDP growth are dictated by the global economic crisis, which is present to a great extent in the Republic of Srpska, taking into consideration its economy, which is not that potent.
It is evident that the most difficult and the most risky year was 2009, as it was the year when the economic crisis left negative consequences in the Republic of Srpska, the most negative effects of the global crisis were felt in 2009, so that the GDP had a negative growth rate at the time. The effects of the negative growth rates from 2009 can still be felt.

\section{Solutions for overcoming the crisis}

Macroeconomic indicators, primarily observed in $\mathrm{B} \& \mathrm{H}$ and its entities, and secondarily in the international environment, indicate that the crisis has produced profound negative effects. The same situation occurs when the negative effects of the crisis are perceived globally. Thus, we believe that we should seek

\begin{tabular}{|c|c|c|c|c|c|}
\hline \multirow{2}{*}{ Indicators } & \multicolumn{5}{|c|}{ Period } \\
\hline & 2007 & 2008 & 2009 & 2010 & 2011 \\
\hline The population of the RS (estimate) & 1.439 .673 & 1.439 .673 & 1.435.179 & 1.433 .038 & \\
\hline Nominal GDP (000 KM) & 7.350 .985 & 8.489 .287 & 8.243 .265 & 8.308 .120 & \\
\hline Real growth rate (in \%) & $6.7 \%$ & $6.2 \%$ & $-2.8 \%$ & $0.8 \%$ & \\
\hline Number of employees & 258.209 & 259.205 & 253.665 & 247.388 & 237.923 \\
\hline Number of unemployed & 139.825 & 135.102 & 139.536 & 145.343 & 153.535 \\
\hline The average net wage (in KM) & 585 & 755 & 788 & 784 & 809 \\
\hline Industrial production growth rate (in \%) & $1.4 \%$ & $16.8 \%$ & $19.0 \%$ & $5.0 \%$ & $4.7 \%$ \\
\hline Export (000 KM) & 1.671 .601 & 1.921 .837 & 1.672 .915 & 2.177 .809 & 2.561 .928 \\
\hline Imports (000 KM) & 3.347 .925 & 4.146 .519 & 3.567 .104 & 4.053 .076 & 4.584 .193 \\
\hline Balance of trade (000 KM) & -1.676 .324 & -2.224 .682 & -1.894 .189 & -1.875 .267 & -2.022 .265 \\
\hline The coverage of imports by exports & $49.9 \%$ & $46.3 \%$ & $46.9 \%$ & $53.7 \%$ & $55.9 \%$ \\
\hline Inflation rate (consumer prices, \%) & $1.1 \%$ & $7.2 \%$ & $-0.4 \%$ & $2.5 \%$ & $3.9 \%$ \\
\hline Foreign direct investments (000 KM) & 1.946 .688 & 165.675 & 104.500 & & \\
\hline
\end{tabular}

Table no. 4: Basic macroeconomic indicators RS (2007-2011)

Source: www.komorars.ba 


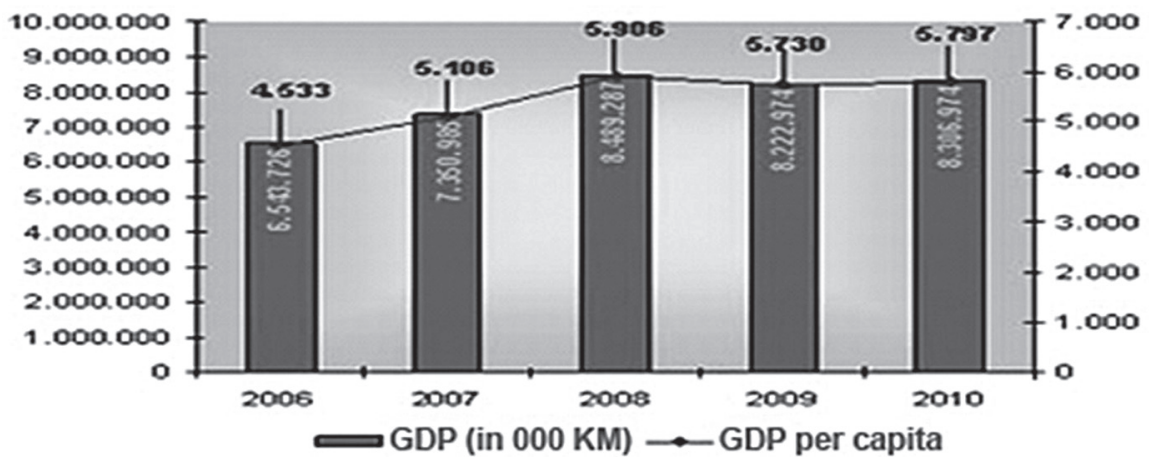

Chart No.8: GDP (in 000 KM) and GDP per capita (KM) 2006-2010

Source: www.komorars.ba

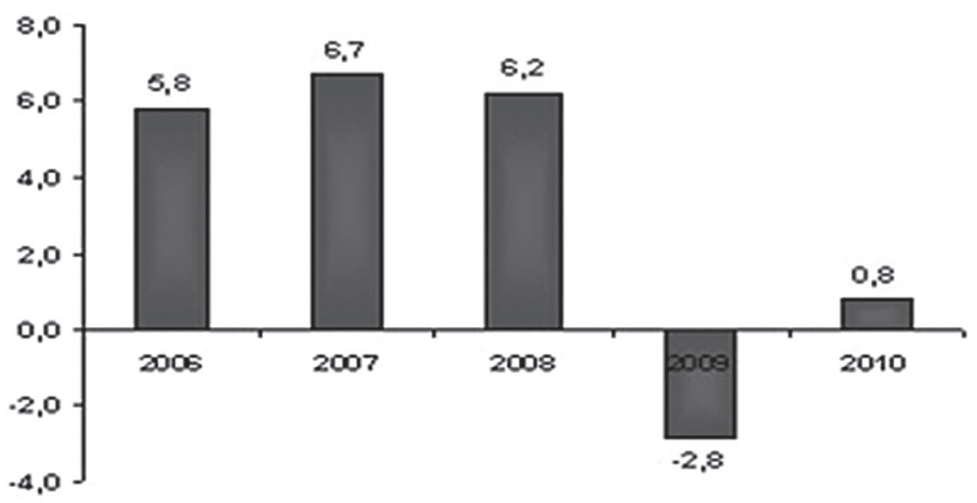

Chart No. 9: Real GDP growth rate (in \%) for the period 2006-2010

Source: www.komorars.ba

the best possible solutions for resolving the crisis. Such resolutions should contain clearly defined objectives necessary to be achieved. In order to achieve such goals, the best policies and the best possible solutions should be put into practice. The current economic model is a typical one, mainly because it is based on high public spending, incurring into debt, creating deficit, all of which lead to a "debt bondage". Therefore, we believe that the appointment of the best possible solutions should be sought via the best possible solutions. The well-being of the society is everyone's goal, particularly if perceived through the political and economic prism. This goal can be achieved only in the long run through the long-term development and the equitable distribution of national income. Our first goal, which, in our opinion, might be a good direction to the best solutions possible, is to raise the rate of economic growth that will lead to the increase of employment rate, up to its full capacities, thus further improving the standard of living. Our subsequent goals would be to increase the investments, production capacities, exports and reduce imports, which would lead to overcoming the current situation, that is to say - the crisis.

The desirable policies in pursuing these goals that could lead to overcoming the crisis on the global level and the level of $\mathrm{B} \& \mathrm{H}$ and its entities, include the following:

- Industrial policy (as the most important policy, in particular the increase of domestic production with the yet unused resources),

- Regional development policy,

- Fiscal policy,

- Monetary policy,

- Social policy,

- Policy of the state administration. 
All these policies require serious analysis and extensive research in order to produce better solutions that will serve as guidelines for resolving the global crisis.

\section{CONCLUSION}

The previous macroeconomic analysis of Bosnia and Herzegovina and the international environment clearly shows that the global crisis has had profound negative effects on those economies. The responsibility for such a poor macroeconomic situation could be assigned to everyone: politics, economies, governments, academies and media. It is clear that the neoliberal system is in the profound crisis and that a complete transformation of the system is necessary in order to overcome the crisis. Such system has become a typical one, since it has made the rich - richer and the poor - poorer. It is not our opinion that the solution would be to pursue certain repairs or changes within such system. The main reason lies in the fact that the system has faced a decline or stagnation of GDP, high indebtedness, production decrease, unemployment increase, great deficits and progress towards debt bondage. Stabilisation of the economy within the current model is only possible through decreasing the living standards of already impoverished citizens. Such a policy would burden the people, and the badly designed policy would be continued via the current neoliberal model (Juričić, 2011).

Directions and guidelines for resolving the crisis are not simple and are difficult to define, as ad hoc solutions, especially in the short term. It is necessary to define the goals first, and then the policy, which could help to achieve such goals. The key objective should be the prosperity of society. Achieving this goal entails sub-goals to be defined in order to achieve the final goal. High, sustainable rates of economic growth, full employment rate with a uniform distribution of national income are the objectives and the conditions for achieving prosperous society. In order to reach the key goals and sub-goals, it is necessary to promote and implement policies that will contribute to accomplishing those goals. (Juričić, 2011). Namely, the following policies should be implemented:

- Industrial policy,

- Fiscal policy,

- Monetary policy,

- Regional policy,
- Social policy,

- Public administration policy.

The implementation of these policies should start immediately. They represent the guarantee for achieving the goals, but not in the short term. Therefore, it is necessary to provide willingness, commitment and time. These would be the key objectives and policies, which should serve as directions and guidelines for overcoming the crisis in $\mathrm{B} \& \mathrm{H}$.

\section{REFERENCES}

Acocella, N. (1998) Fundations of economic policy: values and techniques. Cambridge: Cambridge University Press.

Agencija za rad i zapošljavanje Bosne i Hercegovne. Bilten br. 6 [online]. Available from: http://arz.gov.ba/publikacije/bilteni/?id=279 [accessed 5 July 2012]. (in Serbian)

Auerbach, A., Feenberg, D. (2000) The Significance of Federal Taxes as Automatic Stabilizers. The Journal of Economic Perspectives. 14 (3), 37-56.

Babić, M. (2007) Makroekonomija. 15. izd. Zagreb: Mate. (in Croatian)

Communication from the commission to the European council: A European Economic Recovery Plan. Commission of the European Communities [online]. Available from: http://ec.europa.eu/economy_finance/publications/publication13504_en.pdf [accessed 15 September 2012].

Čaušević, F. (2009) Globalna recesija i njene refleksije na Bosnu i Hercegovinu. Forum Bosnae. 47 (2009), 61-81. (in Serbian)

Dolls, M., Fuest, C., Peichhi, A. (2009) Automatic Stabilizers and Economic Crisis: US vs. Europe. Discussion Paper No. 4310 [online]. Available from: http://ftp.iza. org/dp4310.pdf [accessed 15 August 2012].

Freedman, C., Kumhof, M., Laxton, D., Lee, J. (2009) The Case for Global Fiscal Stimulans. International Monetary Fond [online]. Available from: http://www.imf. org/external/pubs/ft/spn/2009/spn0903.pdf [accessed 8 September 2012].

Global Economic Prospects: Crisis, Finance and Growth. World Bank [online]. Available from: http://siteresources.worldbank.org/INTGEP2010/Resources/ GEP2010-Full-Report.pdf [accessed 5 July 2012].

Global Wage Report 2008/09. Geneva: International Labour Office [online]. Available from: http://www.ilo. org/wcmsp5/groups/public/---dgreports/---dcomm/ documents/publication/wcms_100786.pdf [accessed 15 September 2012].

Godišnji izveštaj 2010. Centralna banka Bosne i Hercegovine [online]. Available from: http://www.cbbh. ba/files/godisnji_izvjestaji/2010/GI_2010_bs.pdf [accessed 2 September 2012]. 
Hodžić, K. (2010) Stanje privrede i mjere anticiklične ekonomske politike Bosne i Hercegovine [online]. Available from: http://unvi.edu.ba/Files/zbornici/ ZBORNIK\%20RADOVAnet.pdf [accessed 1 September 2012]. (in Serbian)

Initial lessons of the Crisis. IMF [online]. Available from: http://www.imf.org/external/np/pp/eng/2009/020609. pdf [accessed 19 October 2012].

Jurčić, Lj. (2011) Velika transformacija za izlaz iz krize. Acta Economica. 9 (14), 79-95. (in Serbian)

Jurković, P. (2002) Javne financije. Zagreb: Masmedia. (in Croatian)

Kozarić, K. (2009) Uticaj globalne finansijske krize na Bosnu i Hercegovinu [online]. Available from: http://www. cbbh.ba/files/specijalne_teme_istrazivanja/sti_01_09_ bs.pdf [accessed 15 August 2012].

Kozarić, K., Salihović, A (2010) Krizno komuniciranje u finansijskim institucijama [online]. Available from: http://www.cbbh.ba/files/specijalne_teme_istrazivanja/sti_01_10_bs.pdf [accessed 15 August 2012].

Pollin, R. (2009) Tools for a New Economy: Proposals for a Financial Regulatory System. Boston Review. [online]. Available from: http://www.bostonreview.net/ BR34.1/pollin.php [accessed 10 September 2012].

Pommier, S. (2006) Fiscal Shocks and Automatic Stabilizers at Work in European Countries. Rennes: University of Rennes 1 [online]. Available from: http://virgo. unive.it/cide/conf/papers/p11.pdf [accessed 7 October 2012].

Puljić, M. (2009) Globalna kriza i Bosna i Hercegovina. Acta Economica. 7 (10), 89-107. (in Serbian)

Puljić, M. (2010) Mjere vlade za prevazilaženje ekonomske krize. Acta Economica. 8 (12), 125-142. (in Serbian)
Spilimbergo, A., et al. (2008) Fiscal Policy for the Crisis.

IMF [online]. Available from: http://www.imf.org/external/pubs/ft/spn/2008/spn0801.pdf [accessed 18 October 2012].

Spilimbergo, A., Symansky, S., Schindler, M. (2009) Fiscal Multiplieres. IMF [online]. Available from: http:// www.imf.org/external/pubs/ft/spn/2009/spn0911.pdf [accessed 1 October 2012].

The Effects of Automatic Stabilizers on the Federal Budget. Congressional Budget Office [online]. Available from: http://www.cbo.gov/sites/default/files/cbofiles/ ftpdocs/121xx/doc12129/04_21_automaticstabilizers. pdf [accessed 10 October 2012].

The long climb. The Economist [online]. Available from: http://www.economist.com/node/14530093 [accessed August 2012].

Tilman, L.M. (2009) Financial Darwinism: create value or self-destruct in a world of risk. Hoboken, N.J.: Wiley; Chichester: John Wiley.

Van den Noord, P. (2000) The Size and Role of Automatic Fiscal Stabilisers in the 1990s and Beyond. OECD [online]. Available from: http://www.oecd.org/eco/ economicoutlookanalysisandforecasts/1880834.pdf [ accessed 10 September 2012].

World Bank (2003) 2003 world development indicators. Washington, D.C.: World Bank

World Economic Outlook: Rebalancing Growth. IMF [online]. Available from: http://www.imf.org/external/ pubs/ft/weo/2010/01/pdf/text.pdf [accessed 1 October 2012].

\section{UPUTSTVA I SMERNICE ZA REŠAVANJE KRIZE (U BOSNI I HERCEGOVINI I NJENIM ENTITETIMA)}

\section{Rezime:}

Ovaj rad se bavi globalnom finansijskom i ekonomskom krizom koja se može smatrati najvećom krizom nakon Drugog svetskog rata. To pitanje je čest predmet rasprave među brojnim analitičarima, predstavnicima vlasti, a naročito je omiljena tema medija. S pravom možemo reći da je reč o krizi neoliberalnog sistema, koja je u velikoj meri uticala na porast imovine bogatih a koja je još više osiromašila siromašne.Takva kriza može se prevazići promenom samog sistema. Stoga je neophodno da postoje uputstva i smernice kako bi se definisali ciljevi za prevazilaženje krize. Pored tih ključnih ciljeva, neophodno je definisati podciljeve, koji će doprineti realizaciji primarnih ciljeva. Neophodno je zagovarati i primenjivati politike koje će olakšati realizaciju jasno definisanih ciljeva i podciljeva. Neke od tih politika su sledeće: industrijska politika, fiskalna politika, monetarna politika, politika regionalnog razvoja, politika javne administracije i socijalna politika.

\section{Ključne reči:}

globalna kriza, makroekonomski indikatori, neoliberalizam, opšte stanje u zemlji, fiskalna politika, industrijska politika, rezolucija, uputstva i smernice.

Received: January 15th, 2012

Correction: March 7th, 2012

Accepted: April 29th, 2012 